American Journal of Pharmaceutical Education 2017; 81 (5) Article 82.

\title{
COMMENTARY
}

\section{Understanding Business Models in Pharmacy Schools}

\author{
David A. Holdford, BPharm, PhD, MS \\ Virginia Commonwealth University School of Pharmacy, Richmond, Virginia \\ Submitted October 27, 2016; accepted February 19, 2017; published June 2017.
}

The objectives of this article are to define business models, contrast the business models in pharmacy schools, and discuss issues that can arise from misunderstandings about whom pharmacy schools serve and how they do so.

Keywords: business model, pharmacy, education, graduate, research

\section{INTRODUCTION}

The term "business model" is becoming increasingly common in education literature, although it is often used imprecisely. ${ }^{1}$ This loose and sometimes incorrect language can result in gross oversimplifications and confusion among academics about the business of education. Some conclude that education is really a higher calling and that attention to business models will lead educators in the wrong direction. ${ }^{2}$ Others take the opposite view, seeing education as a business like any other where the primary goal is to maximize profits. ${ }^{3}$ Neither of these opposing viewpoints are useful because they oversimplify and misrepresent the real nature of education and business models.

Explicit discussions about business models in pharmacy education are uncommon. Rupp has discussed the importance of business models in aligning interests of faculty and administrators ${ }^{4}$ and branding pharmacy schools. ${ }^{5}$ He concluded that misunderstandings about business models can lead to conflict between faculty and administrators relating to maintaining high academic standards and the sustainability of tuition revenues. ${ }^{5}$ No other specific discussions occur in the pharmacy literature.

Nevertheless, implicit conversations about business models occur throughout the literature, because they are fundamental to any viable activity in pharmacy education. Business models are implicitly referenced when discussing most major topics in pharmacy education including faculty workforce issues, affordability and quality of graduate and professional training, and the sustainability of pharmacy schools. Business models answer questions like "Who do we want to serve?" and "How can we do so in a profitable way over time?"

Nothing in this article is unique to US pharmacy schools. Anecdotal conversations with colleagues outside of the US indicate that similar discussions are occurring at their institutions about the direction of pharmacy education and research. That is to be expected because the rules of business are universal, and issues related to business models are relevant to pharmacy schools across the globe.

\section{What Is a Business Model?}

Before proceeding any further, it is important to define and describe business models. A business model is simply a general description about how a business or institution serves or intends to serve customers over time. ${ }^{6}$ It is a large picture view of the institution that contains most of the features of business plans but with less detail and specificity.

Business models are crucial in strategic planning and communicating broad details about enterprises. They vary across businesses, but all contain at least three primary components. ${ }^{3}$

Customer value proposition (CVP): The CVP is a description of how a business creates value for customersby providing solutions to important problems better than competing options. It is the case made for why a customer should choose one business over another.

Resources and processes: Resources refer to the people, technology, equipment, facilities, location, and other things needed to deliver the CVP, while processes describe operations and management of the business. In pharmacy education, these resources and processes include faculty and staff, administrators, programs, courses, curricula, policies, key performance indicators, and other things associated with academia.

Profit formula: This formula defines how sufficient revenues are generated by the business to cover the costs of providing the CVP over time.

All business models describe how these three interdependent components attempt to achieve the overall mission of organizations. To be sustainable, the CVP provided by resources and processes must generate enough revenues to cover costs over the long term. 


\section{American Journal of Pharmaceutical Education 2017; 81 (5) Article 82.}

\section{TYPES OF BUSINESS MODELS}

Business models can be described as falling into three generic types: solution shops, value-adding businesses, and facilitated networks. ${ }^{7}$ The latter, facilitated networks, provides value by connecting individuals and organizations via platforms like social media networks such as Facebook and YouTube. AACP can be classified as a facilitated network because its value lies in connecting academics and institutions for the purpose of advancing pharmacy education.

Few pharmacy schools operate under the facilitated network model, so they will not be discussed further in this article. Solution shops and value-adding models will be the focus instead because they are the norm in higher education, ${ }^{8}$ including pharmacy schools in the US and throughout the world.

Researchers Work in Solution Shops. Solution shops are institutions that solve complicated problems having no clear solutions. The solution shop model consists of work done by experts who draw upon deep experience, training, and skills to serve unique and complex client needs. Experts provide value by solving hard problems better than anyone else. They support themselves by being compensated by clients who pay a premium for cutting edge expertise and work.

Funded research programs in pharmacy schools follow the solution shop business model. They provide highly customized solutions to clients. Research questions are unique and require well-trained individuals and teams who use innovative methods to investigate and interpret research about difficult problems. They are supported by revenue from grants and contracts.

Educators Operate in Value Adding Process (VAP) Businesses. VAP businesses are intermediaries in marketing channels that take something from one channel partner, add value, and then pass it on to the end consumer or next channel intermediary. Any enterprise that uses rulesbased and standardized processes is a VAP business. They sustain themselves by being compensated for the additional value they provide within the process.

Most PharmD and non-thesis pharmacy graduate programs use VAP models. These programs are intermediaries that accept students from undergraduate channel partners. They add value through didactic, experiential, and cocurricular experiences, and send the new and improved students to employers or post-graduate educational partners. Programs are heavily guided by professional standards and guidelines which seek to standardize the skills and capabilities of pharmacy graduates. These VAP businesses support themselves by receiving sufficient tuition and other revenue to cover the costs of providing the additional educational value.

\section{Why are Business Models Important?}

Business models are important to pharmacy schools and academics because they detail how schools and colleges achieve their missions. Business models make explicit the assumptions behind each element of the business and are important for the following reasons:

Business models help communicate strategy. The basic elements of business models can be provided on a single page. ${ }^{9}$ They allow educators and researchers to step back from day-to-day tasks to see a concise overview of how they are achieving the institution's mission. Conversations can occur around specific elements of the model to ensure that everyone is on the same page about who their customers are, what the school's value proposition(s) is, what best ways to communicate that value proposition are, and what other components of the model are.

Business models help align efforts. A vague understanding of a school's business model can lead faculty and administrators to head off in different directions while trying to achieve the mission. Misaligned efforts can be wasteful, even counterproductive. At best, lack of coordinated efforts can put a drag on the efficiency and effectiveness of a pharmacy school. At worst, it can lead to a downward spiral of unsustainable initiatives that result in a school's inability to remain open.

Understanding and accepting a school's business model(s) focuses individuals on what is important for success. Shared understanding of business models can reduce conflict between faculty and administration and lead to more coordinated efforts in education, service, and scholarship.

Business models help schools to respond to perils. The status quo for pharmacy schools worldwide is increasingly perilous. PharmD programs in the US and some other countries are competing for fewer students, and competition restricts the ability of schools to raise additional tuition through larger class sizes or rate increases. Many schools lack funding or sufficient numbers of trained educators to meet their nations' health care education needs. Some pharmacy schools are trying to address gaps in education by expanding their research efforts. However, research programs often see shrinking funding and more competition for funds from other research organizations. Increasing costs and revenue shortages are forcing schools to make hard choices about their educational and research programs.

Business models are helpful to schools in identifying when current value propositions are too costly to maintain, and they can suggest ways to adapt. For example, if schools find it difficult to recruit sufficient numbers of qualified PharmD candidates to fill class sizes, alternative business models might suggest ways to reduce costs or seek new funding streams. 


\section{American Journal of Pharmaceutical Education 2017; 81 (5) Article 82.}

\section{CONTRASTING EDUCATION AND RESEARCH BUSINESS MODELS}

Pharmacy schools and colleges operate under two primary business models: education and research. All pharmacy schools work under the education business model because it impossible to be a school or college without educating students. Many other schools add an additional one, the research business model. A third potential model exists, the service business model. This model is seen in academic health care systems where faculty members are expected to provide billable services that generate revenue for the school. The service business model will not be considered in this article because it is less common and relatively unimportant compared to education and research. Table 1 illustrates the fundamental differences between the education business model and research business model.

\section{Education Business Models}

Pharmacy schools using this business model see their principal mission as preparing individuals for the practice of pharmacy. The outcome of the educational process is "a professional," and the key activities associated with achieving this outcome are educating and mentoring. It is a value adding process in which the generic value proposition made to pharmacy students, employers, the general public, and other customers of the education business model is, "Our graduates provide exceptional, costeffective care to patients." This value proposition appeals to the primary customer of professional education, the patient, ${ }^{10}$ and all other customers. For that value proposition, schools receive tuition and donations of time, effort, and money from people and organizations that support the education mission. Success with this model comes from making the case that an institution does a more effective job than competitors in preparing students for a future in the pharmacy profession. Infrastructure and salaries support the education of students.

The major challenge to the pharmacy education business model is the temptation of university officials to see pharmacy programs as revenue generators to support other less profitable programs like liberal arts. Money-making programs like pharmacy education can be harmed if university administrators take disproportionate amounts of student revenue without adequately reinvesting it into the schools. A university's need for cash from pharmacy programs can hurt a school's value proposition and competitiveness, especially if it results in above-market tuition rates that are not justified by the quality of education. In a competitive market, students can go to schools offering better value, thereby starving less competitive programs of tuition dollars. Additional funding gaps may further

Table 1. Contrasting Components of Pharmacy School Education and Research Business Models

\begin{tabular}{|c|c|c|}
\hline Model Components & Education Business Model & Research Business Model \\
\hline Mission & $\begin{array}{l}\text { To prepare individuals to enter the } \\
\text { practice of pharmacy and function } \\
\text { as professionals }\end{array}$ & $\begin{array}{l}\text { To contribute to understanding and } \\
\text { knowledge about pharmaceuticals and } \\
\text { medication use processes }\end{array}$ \\
\hline Outcome & A professional & Knowledge \\
\hline Key Activities & Educating, mentoring & Research, grant writing, publishing \\
\hline Generic Category of Business Model & Value-Adding Process & Solution Shop \\
\hline $\begin{array}{l}\text { Primary Customers: people or businesses } \\
\text { you serve over all other customers }\end{array}$ & $\begin{array}{l}\text { Patients who will receive care from } \\
\text { pharmacy graduates }\end{array}$ & $\begin{array}{l}\text { Institutions and businesses that fund and } \\
\text { benefit from research }\end{array}$ \\
\hline $\begin{array}{l}\text { Secondary Customers: other people } \\
\text { you may serve }\end{array}$ & $\begin{array}{l}\text { Students, funders of professional } \\
\text { education, employers of graduates, } \\
\text { professional societies, the health } \\
\text { care system, general public }\end{array}$ & $\begin{array}{l}\text { Students, employers of graduates, funders of } \\
\text { graduate education, journals, scientific } \\
\text { societies, general public }\end{array}$ \\
\hline $\begin{array}{l}\text { Revenue and resources needed to } \\
\text { sustain your value proposition }\end{array}$ & $\begin{array}{l}\text { Tuition, fees, service contracts, and } \\
\text { donated cash, material, time, effort }\end{array}$ & Grants, donations, service contracts \\
\hline Costs generated in serving customers & $\begin{array}{l}\text { Salaries and benefits, educational } \\
\text { infrastructure and overhead }\end{array}$ & $\begin{array}{l}\text { Salaries and benefits, educational } \\
\text { infrastructure and overhead, research } \\
\text { infrastructure and overhead }\end{array}$ \\
\hline
\end{tabular}




\section{American Journal of Pharmaceutical Education 2017; 81 (5) Article 82.}

degrade a school's value proposition and eventually lead to a program's termination.

\section{Research Business Models}

The primary mission of institutions using a research business model is to contribute to the knowledge base about a topic or group of topics. As mentioned earlier, the research business model in pharmacy schools coexists with the education business model. However, it is distinct because the mission and processes of achieving that mission are different.

In pharmacy institutions, the mission of the research business model is to contribute to understanding and knowledge about pharmaceuticals and medication use processes. This mission may focus on a specific area like pharmacology or medicinal chemistry, or it may seek knowledge across the entire medication product life cycle; from bench to population-based research.

Unlike the education model, teaching is only a byproduct of the research business model. The main purpose of research is knowledge, and students add value by contributing to the scientific productivity of faculty advisors. Students' roles in the business model are to conduct research, write grants, and disseminate knowledge through publishing and presentations.

Although graduate education is an integral part of most research programs, it is not essential to the research business model. Graduate students can be replaced by post-doctoral fellows and research technicians in this model. Indeed, many successfully funded research programs do not use graduate students in their operations, preferring to hire post docs who are not distracted by coursework and other educational demands.

The pharmacy research business model acts as a solution shop for clients like governmental agencies, pharmaceutical companies, and other institutions that have complex questions that need to be answered. The value proposition is "We provide meaningful, costeffective answers to complex research questions." This value proposition competes for customers with other pharmacy and non-pharmacy educational institutions that conduct similar research. It also competes against contract research organizations whose only mission is research, and clients who decide to conduct research inhouse rather than outsource it to pharmacy schools or other researchers. Revenue from external grants (eg, $\mathrm{NIH}$ ), donations (eg, alumni gifts in support of research), and service contracts (eg, pharmaceutical industry) fund the research business model. This money supports research infrastructure and salaries engaged in research.

\section{POTENTIAL PROBLEMS IN USING TWO OR MORE BUSINESS MODELS}

Tension can exist when schools seek to pursue both education and research business models because it requires making choices on priorities and allocation of efforts. This tension is commonplace in most researchintensive pharmacy schools where conflicts revolve around the competing demands of education and research. Potential problems arise from the following sources.

Not Knowing the Economic Value of Choices. Pharmacy schools are businesses. They provide educational or research services in exchange for money or other form of value, the classic definition of a service business. Yet many academics do not understand the economic value of the choices they make in their jobs.

One reason is that the complexity of research and educational tasks make it difficult to understand each person's relative contribution. For example, how does one compare research effort to education effort? This can lead to arguments about relative faculty workloads or contributions to the business model. Attempts to quantify faculty members' contributions to the education business model ${ }^{11}$ have been met with skepticism, although demands to make higher education more affordable will likely lead to further efforts like this.

Showing uneven respect to different business models. In academia, some business models are viewed as more important than others. The preference of research-intensive schools, as the name implies, is for research over education. This preference is codified within the promotion and tenure processes of these schools. Their call to faculty is not "teach-or-perish." Rather, the path to promotion and tenure is to receive research funding and burnish one's reputation through publications and presentations. Exceptional teachers can be promoted at some institutions, but greater recognition is usually accorded to researchers. For instance, a faculty member who receives a $\$ 250,000$ research grant will generally garner more praise than one who generates an additional $\$ 250,000$ in tuition.

According greater respect to research is based upon the assumption that research dollars are more valuable than tuition dollars coming into the institution. From a reputational aspect, this assumption might be correct because institutional reputations are heavily influenced by NIH funding and other sources of research revenue. Still, tuition dollars can be used to fund the mission of pharmacy schools as well as research dollars. One might also question why less respect is given to professional education, because without it, there is no pharmacy school. If they are equally important, equal respect needs to be shown to both teaching and research contributions. 


\section{American Journal of Pharmaceutical Education 2017; 81 (5) Article 82.}

Using one business model to subsidize another. Money is a fungible resource. This means that tuition dollars can support research and research revenue can support education. Although numerous restrictions exist in moving money within pharmacy schools, there is enough flexibility for revenue from one business model to subsidize another.

A common assumption in pharmacy education is that research revenues subsidize professional education at research-intensive schools. Although this may be true at some state institutions that are forced by state legislatures to charge below-market tuition rates, research does not always generate positive cash flow for schools. In reality, research programs often lose money at institutions. ${ }^{12}$

Research programs in pharmacy schools operate under a portfolio strategy similar to pharmaceutical companies. In a portfolio strategy, pharmaceutical companies invest in a range of research initiatives in the hope that a few will be blockbusters, some will be moderately successful, and the rest will break even. The most successful products fund the other initiatives. Pharmacy schools act similarly by investing in the research programs of individual faculty members and teams.

In the beginning stage of most individual research programs, a negative cash flow will exist that must be made up from some other source. That source might be other research programs, but it can also come from the educational budget. In fact, there is good chance that new tenure-track faculty who are protected from teaching responsibilities will have some of their protected salary paid for by tuition revenue.

Even when faculty have established research programs, grants may not cover all research expenses. This is due to a bias in academia for chasing revenue over managing the costs of attaining that revenue. Faculty members are feted for receiving a million dollar research grant, even if that grant costs more than one million dollars to administer. In academia, this type of grant is considered a "success." In business, a program that generates less revenue than it costs to run is labeled "unprofitable."

Schools with too many unprofitable research programs need to find some other source of funding, including tuition revenue, to cover those losses. The problem in academia is that the complexity of university accounting systems make it difficult to differentiate profitable and unprofitable research programs. Therefore, the automatic assumption that research subsidizes the educational business model in research-intensive universities should always be questioned.

\section{Education, Research, and Service Have Different Roles in Business Models}

The tripartite mission in academic institutions is education, research/scholarship, and service. The relative roles and importance of these three elements varies depending on the institution's business model(s). Table 2 illustrates how.

In the research business model, grants and contracts are critical for supporting the infrastructure and running of the school. An emphasis is placed on pursuing the scholarship of discovery because that is what is more likely to be funded by governmental agencies. Scholarship of discovery also helps get the school's name out in publications and press. The reputation from that scholarship draws more funding, attracts new research faculty, and improves school ratings among peer institutions. In turn, reputation from this scholarship attracts students who want to attend the top pharmacy schools. Successful research can also generate excess revenue to support educational programs, allow faculty to serve on funding agencies, and attract exceptional graduate students who can contribute to the research program.

In the education model, revenue from tuition is the primary source of support for educational infrastructure

Table 2. Role of Research, Education, and Service in Pharmacy School Business Models

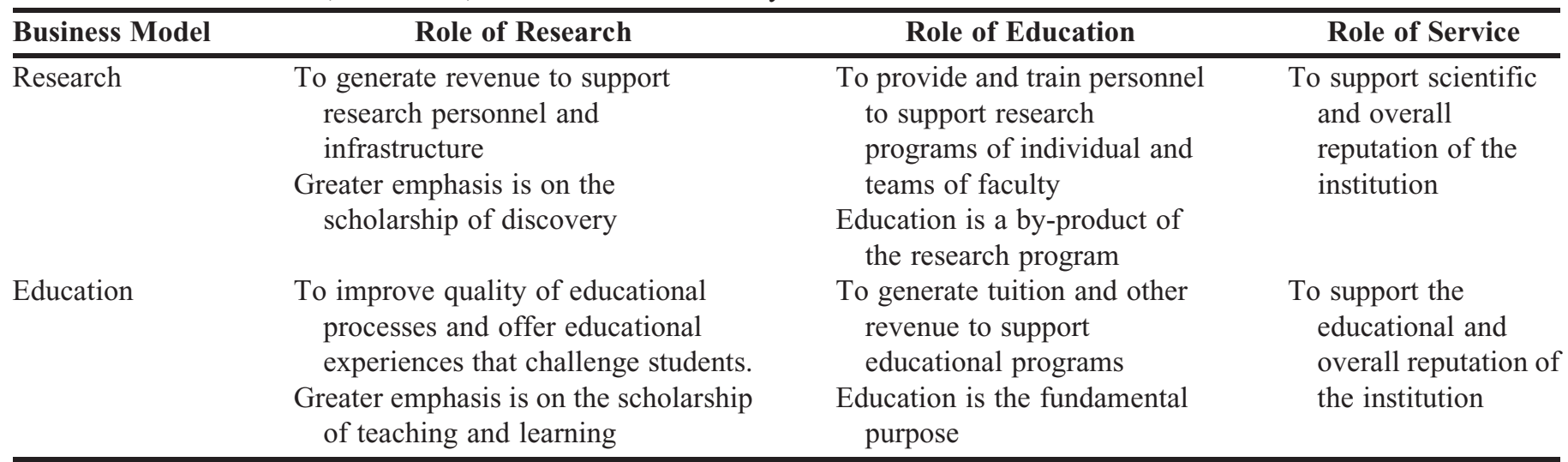




\section{American Journal of Pharmaceutical Education 2017; 81 (5) Article 82.}

and operations, so revenue from scholarship of discovery is not a focus. Instead, scholarship of teaching and learning is emphasized because the knowledge and skills learned can enhance the school's value proposition by improving the quality and efficiency of education. Exceptional and innovative teaching should result in students who are prepared to succeed in advanced practice experiences and after graduation. Excellence in graduates should draw the attention of employers and make students more competitive for post-graduate opportunities like PGY1 and PGY2 residencies. Furthermore, positive word-of-mouth discussions by alumni and students about their educational experiences make it easier to recruit additional good students. In place of service to funding institutions, faculty members are encouraged to serve local and state professional associations, thereby enhancing relationships with potential experiential preceptors and potential donors to the school.

Academics who understand their business model(s) are better able to focus on the correct educational, research, and service activities for their institutions. It can also help new graduates with interest in academia select the schools where they can best succeed. This can reduce the number of new faculty members who are disheartened to learn that their academic position is not really what they hoped it would be.

\section{THE BEST BUSINESS MODEL FOR TRAINING PHARMACISTS}

Which type of business model results in better pharmacists - research or education? The answer depends on how well a pharmacy school implements and runs its business model(s). Both types turn out excellent pharmacists when they take advantage of their model's strengths.

Schools that focus on an education business model have a natural advantage because they can concentrate on adding value through teaching. Their costs can be kept low because they only need to support educational infrastructure and operations, thereby avoiding the additional costs of expensive laboratories, funding infrastructure, and research faculty. Their research and scholarship can focus on improving operations to identify ways to educate better and more efficiently. A singular focus on education can attract great teachers who choose not to follow the tenure and promotion career model, and it can prevent having great researchers in classrooms who are unable or unwilling to teach.

Conversely, a compelling argument can be made that research-intensive schools have a true advantage in educating pharmacy students. They typically have a strong public image built upon their research programs. Whether deserved or not, success in research funding is often used by the public as a surrogate for quality in pharmacy school ratings. Indeed, the top 25 pharmacy schools in the US News and World Report's survey all have a significant research focus. ${ }^{13}$

Schools with excellent reputations have an inherent advantage because success tends to breed success. Good reputations attract the best students and faculty members. A good reputation generally makes it easier to recruit experiential training sites and solicit donations from alumni and other stakeholders. Well-funded research institutions can better afford educational technology, new buildings, and support staff. Schools can even keep tuition artificially low by tapping into diverse revenue streams from research and donations.

Still, these natural advantages do not ensure success for either model in training pharmacists. Education-focused schools must rely on a single source of income to fund their value proposition. Tuition deficits from shrinking student applicant pools cannot be covered from other revenue sources, so pharmacy schools may be tempted to accept marginal students in their programs. Marginal students can drag down the overall quality of educational experiences for other students, faculty, and preceptors. A few bad experiences with marginal students can damage a school's reputation and ability to achieve an educational mission. On the other hand, research-intensive schools can suffer the hubris of an excellent reputation and become complacent with their education business model. Overconfidence in their capabilities can blind them to deficiencies in professional programs that might hurt their ability to pass accreditation standards and prepare students for practice.

\section{CONCLUSION}

Pay attention to the fundamental issues behind most conversations in pharmacy schools, and you will see that they revolve around business models. Almost every discussion revolves around the school's mission, whom it serves, and how to achieve it in a viable manner. This is the essence of business models. It is incumbent on academics in pharmacy schools to understand their business model(s) and to help shape their evolution to changing realities in pharmacy education.

\section{REFERENCES}

1. Denna E. The business model of higher education. Educ Rev. 2014;49(2).

2. Katatopes P. The "business model" is the wrong model. Inside Higher Ed. https://www.insidehighered.com/views/2009/02/16/ business-model-wrong-model. Published 2009. Accessed September 5, 2016.

3. Ruch R. Higher Ed, Inc.: The Rise of the For-Profit University. Baltimore, MD: Johns Hopkins University Press; 2001. 


\section{American Journal of Pharmaceutical Education 2017; 81 (5) Article 82.}

4. Rupp MT. Aligning the interests of administration and faculty to improve pharmacy student retention. Am J Pharm Educ. 2011;75(9): Article 190

5. Rupp MT. Branding a college of pharmacy. Am J Pharm Educ. 2012;76(9):Article 166.

6. Holdford DA, Carroll NV. Strategic Planning Process. In: Marketing for Pharmacist: Providing and Promoting Pharmacy Services. 3rd ed. Richmond, VA: PharmacoEnterprise Publishing; 2015:66-85.

7. Hwang J, Christensen CM. Disruptive innovation in health care delivery: a framework for business-model innovation. Health Aff (Millwood). 2008;27(5):1329-1335.

8. Christensen $\mathrm{C}$, Eyring H. The Innovative University: Changing the DNA of Higher Education from the Inside Out. San Francisco, CA: Jossey-Bass; 2011.
9. Osterwalder A, Pigneur Y. Business Model Generation: A Handbook for Visionaries, Game Changers and .... Hoboken, NJ: John Wiley and Sons; 2010.

10. Holdford DA. Is a pharmacy student the customer or the product? Am J Pharm Educ. 2014;78(1):Article 3.

11. Vedder R, Matgouranis C, Robe J. Faculty productivity and costs at the University of Texas at Austin: a preliminary analysis. Cent Coll Afford Productiv. 2011. http://eric.ed.gov/?id=ED536155. Accessed September 16, 2016.

12. Holbrook KA, Sanberg PR. Understanding the high cost of success in university research. Technol Innov. 2013;15(3):269-280. 13. Best Pharmacy Programs | Top Pharmacy Schools | US News Best Grad Schools. U.S. News and World Report. http://grad-schools. usnews.rankingsandreviews.com/best-graduate-schools/top-healthschools/pharmacy-rankings. 2016. Accessed September 30, 2016. 